\title{
Bursaphelenchus pinophilus Brzeski \& Baujard, 1997 (Nematoda: Parasitaphelenchinae) associated with nematangia on Pityogenes bidentatus (Herbst, 1783) (Coleoptera: Scolytinae), from the Czech Republic
}

\author{
Václav ČERMÁK ${ }^{1, *}$, Paulo VIEIRA ${ }^{2}$, Vladimír GAAR ${ }^{1}$, Mária ČUdeJKovÁ ${ }^{1}$, \\ Jiří FOIT ${ }^{3}$, Kateřina ŠIROKÁ ${ }^{1}$ and Manuel MOTA ${ }^{2}$
}

The occurrence of Bursaphelenchus species in the Czech Republic is poorly known, the first report of the genus being made by Kubátová et al. (2000) who reported the association of $B$. eremus with the hyphomycetous microfungus, Esteya vermicola, and the bark beetle, Scolytus intricatus, collected from Quercus robur, in central Bohemia. To date, four other species have been reported from the country, namely B. fungivorus (Braasch et al., 2002), B. hofmanni (see Braasch, 2001), B. mucronatus (see Braasch, 2001) and B. vallesianus (Gaar et al., 2006). More recently, a survey for Bursaphelenchus species associated with bark- and wood-boring insects in the Czech Republic identified B. pinophilus Brzeski \& Baujard, 1997 from the Moravia region. Although this represents a new country record, it was also associated with nematangia on the hind wings of a new insect vector.

A total of 404 bark- and wood-boring insects were collected from declining or symptomatic trees and screened for the presence of Bursaphelenchus. Bark and longhorn beetles were captured manually after debarking parts of the trunk displaying symptoms of insect attacks. Longhorn beetle larvae were also collected together with logs cut from the trunk. Logs were kept at room temperature in the laboratory until insect emergence. Each adult insect was individually dissected in water and examined for nematodes. All nematodes resembling dauer juveniles of Bursaphelenchus were collected and identified by molecular characterisation using a region of ribosomal
DNA (rDNA) containing the internal transcribed spacer regions ITS1 and ITS2. ITS-RFLP analyses using five restriction enzymes (AluI, HaeIII, HinfI, MspI, RsaI) were performed to generate the species-specific profile according to Burgermeister et al. (2009). Species identification was also confirmed by morphological data after culture of the dauers on Botrytis cinerea Pers. ex Ft., growing in 5\% malt extract agar.

During this survey, only species belonging to the Curculionidae, subfamily Scolytinae, revealed the presence of nematodes belonging to Bursaphelenchus. Dauers of this genus were found aggregated under the elytra in nematangia formed at the root of the hind wings (Fig. 1). The dauers were identified from 12 individuals of Pityogenes bidentatus (Herbst, 1783) (Coleoptera: Scolytinae) collected under the bark of Pinus sylvestris trunks. Each insect carried $c a$ 10-100 dauers. The ITS-RFLP patterns of the dauers so obtained confirmed the identification of B. pinophilus associated with this insect species.

Bursaphelenchus pinophilus has been found mainly in Europe and has been reported from various countries such as Poland (Brzeski \& Baujard, 1997), Germany (Braasch, 2001), and Portugal (Penas et al., 2007). The recent detection of this species associated with dead $P$. koraiensis in Korea (Han et al., 2009) expands its geographical distribution and potential importance. It has been found associated only with Pinus species, but very little is known about the insect vector. The bark beetle, Hylurgus ligniperda, was initially suggested as the insect vector by Pe-

\footnotetext{
${ }^{1}$ State Phytosanitary Administration, Division of Diagnostics, Šlechtitelu 773/23, 77900 Olomouc, Czech Republic

${ }^{2}$ Universidade de Évora, Lab. Nematologia/ICAAM, 7002-554 Évora, Portugal

${ }^{3}$ Mendel University in Brno, Department of Forest Protection and Game Management, Zemědělská 1, 61300 Brno, Czech Republic
}

* Corresponding author, e-mail: vaclav.cermak@ srs.cz

Received: 9 August 2011; revised: 7 November 2011

Accepted for publication: 7 November 2011

Keywords: bark beetle, Bursaphelenchus sexdentati group, new host, new record, Pinus sylvestris. 

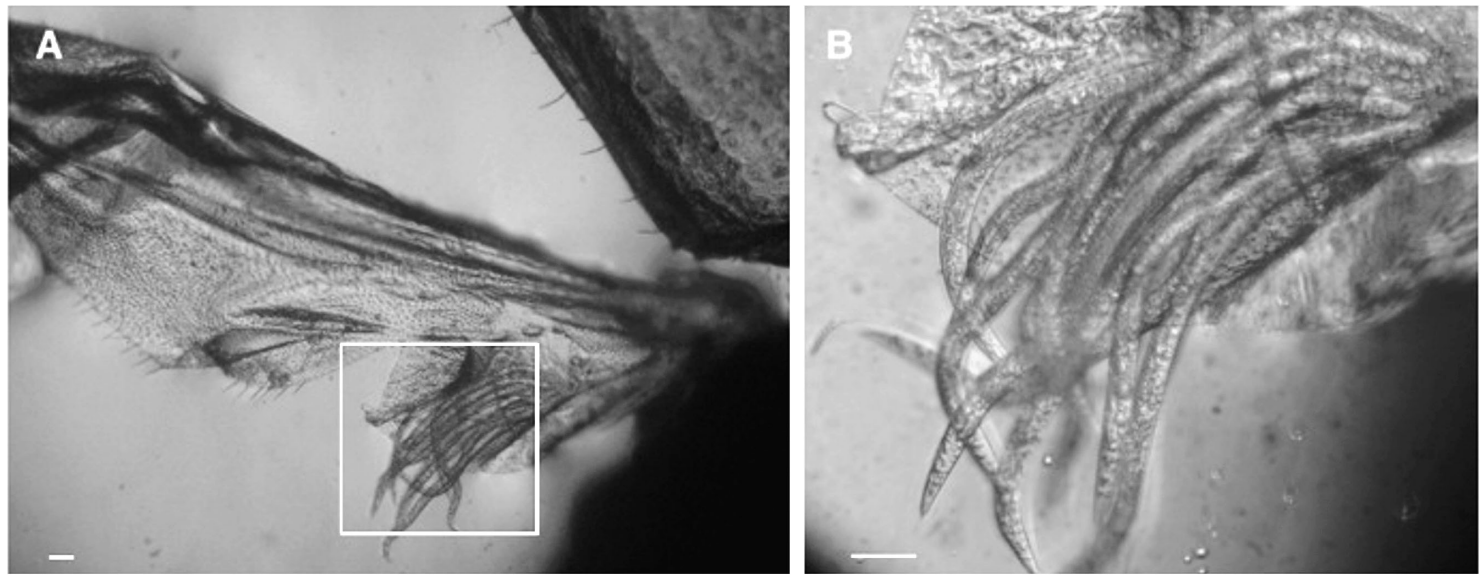

Fig. 1. Bursaphelenchus pinophilus dauers associated with Pityogenes bidentatus. A: Light micrograph of dauers under insect vector hind wing; B: Enlarged view of delineated area in A, showing position of dauers. (Scale bars $=50 \mu \mathrm{m}$.)

nas et al. (2006), although the nematode associated with this insect was later reclassified as $B$. sexdentati by morphological and molecular analysis (Penas et al., 2007). According to the literature, $P$. bidentatus has been cited as a vector of Ektaphelenchus sp. (Kakuliya, 1966) in Georgia, and an unidentified nematode species in Spain (Roberston et al., 2008). Interestingly, B. pinophilus was found in the nematangia formed at the root of the hind wings of $P$. bidentatus. Although this phenomenon is not so common in other Bursaphelenchus species, B. rufipennis has been found recently in such a structure on the hind wings of the insect Dendroctonus rufipennis (Kanzaki et al., 2008). Although other nematode species (e.g., Ektaphelenchus spp.) are frequently found associated within the same nematangia (see Kanzaki et al., 2008), in this particular case, only dauers of $B$. pinophilus were identified. The association between $B$. pinophilus and P. bidentatus represents the first report of this biological association and the association with the Scolytinae strengthens the tight and specific links between this group of Bursaphelenchus species and members of the Scolytinae (Ryss et al., 2005).

\section{Acknowledgements}

This research was partly supported by Portugal-Czech Republic Cultural Agreement Programme (2007-2010) and the Ministry of Education of the Czech Republic, number MSM 6215648902. We thank the anonymous reviewers for their comments.

\section{References}

BRAASCH, H. (2001). Bursaphelenchus species in conifers in Europe: distribution and morphological relationships. EPPO Bulletin 31, 127-142.

BraAsch, H., Bennewitz, A. \& Hantusch, W. (2002). Bursaphelenchus fungivorus - ein Nematode aus der Gruppe der Holznematoden im Pflanzsubstrat eines Gewächshauses und in Holz-und Rindenimport. Nachrichtenblatt des Deutschen Pflanzenschutzdienstes 54, 1-4.

BRZESKI, M.W. \& BAUJARD, P. (1997). Morphology and morphometrics of Bursaphelenchus (Nematoda: Aphelenchoididae) species from pine wood of Poland. Annales Zoologici 47, 305-319.

Burgermeister, W., Braasch, H., Metge, K., Gu, J., SCHRÖDER, T. \& WOLDT, E. (2009). ITS-RFLP analysis, an efficient tool for differentiation of Bursaphelenchus species. Nematology 11, 649-668.

GaAr, V., Zouhar, M., Douda, O., MAreK, M., NovÁkovÁ, E. \& RysáneK, P. (2006). First occurrence of Bursaphelenchus vallesianus in the Czech republic. Pine wilt disease: a worldwide threat to forest ecosystems. International Symposium, 10-14 July, Lisbon, Portugal, p. 62. [Abstr.]

Han, H., Chung, Y.J. \& ShIN, S.C. (2009). First report of Bursaphelenchus pinophilus on Korean pine (Pinus koraiensis). Plant Disease 93, 1354.

KAKULIYA, G.A. (1966). [Nematode fauna of bark beetles from the Borzhomi-Bakurinsk Pass.] Soobschcheniya Akademii Nauk Gruzinskoi SSR 1, 48-64.

Kanzaki, N., Giblin-Davis, R.M., Cardoza, J.Y., Ye, W., RAFFA, F.K. \& CENTER, J.B. (2008). Bursaphelenchus rufipennis n. sp. (Nematoda: Parasitaphelenchidae) and redescription of Ektaphelenchus obtusus (Nematoda: Ektaphe- 
lenchinae), associates from nematangia on the hind wings of Dendroctonus rufipennis (Coleoptera: Scolytidae). Nematology 10, 925-955.

Kubátová, A., Novotný, D., Prášil, K. \& MráčeK, Z. (2000). The nematophagous hyphomycete Esteya vermicola found in the Czech Republic. Czech Mycology 52, 227-235.

Penas, A.C., Bravo, M.A., Naves, P., Bonifácio, L., SousA, E. \& MotA, M. (2006). Species of Bursaphelenchus Fuchs, 1937 (Nematoda: Parasitaphelenchidae) and other nematode genera associated with insects from Pinus pinaster in Portugal. Annals of Applied Biology 148, 121-131.

Penas, A.C., Bravo, M.A., Valadas, V. \& Mota, M. (2007). Detailed morphobiometric studies of Bursaphelenchus xylophilus and characterization of other Bursaphelenchus species (Nematoda: Parasitaphelenchidae) associated with Pinus pinaster in Portugal. Journal of Nematode Morphology and Systematics 10, 137-163.

Robertson, L., Garcia-Alvarez, A., Arcos, S.C., DiezRojo, M.A., Sanz, R., Martinez, C., Escuer, M., Castresana, L., Notario, A., Bello, A., et Al. (2008). Potential insect vectors of Bursaphelenchus spp. (Nematoda: Parasitaphelenchidae) in Spanish pine forests. In: Mota, M. \& Vieira, P. (Eds). Pine wilt disease: a worldwide threat to forest ecosystems. Springer Science + Business Media B.V., pp. 221-233.

Ryss, A., Vieira, P., Mota, M. \& Kulinich, O. (2005). A synopsis of the genus Bursaphelenchus Fuchs (Nematoda: Aphelenchida: Aphelenchoididae) with a key to species. Nematology 7, 393-458. 